\title{
An Analysis of the Antibiotic Resistance Genes of Multi-Drug Resistant (MDR) Acinetobacter baumannii
}

\author{
Jina $\operatorname{Lim}^{1}$, Gyusang Lee ${ }^{2}$, Yeonim $\mathrm{Choi}^{3}$, Jongbae Kim ${ }^{1}$ \\ ${ }^{1}$ Department of Biomedical Laboratory Science, Yonsei University, Wonju 26493, Korea \\ ${ }^{2}$ MAKRI (Military National Defense) KIA Recovery and Identification), Department of Identification, Scientific Staff, Seoul 06984, Korea \\ ${ }^{3}$ Department of Biomedical Laboratory Science, Songho College, Hoengseong 25242, Korea
}

\section{다제내성 Acinetobacter baumannii의 항생제 내성 유전자 분석}

임진아 ${ }^{1}$, 이규상 ${ }^{2}$, 최연임 ${ }^{3}$, 김종배 $^{1}$

${ }^{1}$ 연세대학교 임상병리학과, ${ }^{2}$ 국방부 유해발굴감식단 감식과, ${ }^{3}$ 송호대학교 임상병리과

\begin{abstract}
Acinetobacter baumannii (A. baumanni) is prevalent in hospital environments and is an important opportunistic pathogen of nosocomial infection. It is known that this pathogen cause herd infection in hospitals, and the mortality rate is remarkably higher for patients infected with this pathogen and already have other underlying diseases. Herein, we investigated the antibiotic resistance rate and the type of resistance genes in 85 isolates of multi-drug resistant $A$. baumannii from the samples commissioned to laboratory medicine in two university hospitals-in hospital A and hospital B-located in Cheonan and Chungcheong provinces, respectively, in Korea. As a result, blaoxA-23-ike and blaoxA-51-ike were detected in 82 stains (96.5\%). These 82 strains of blaoxA-23-like producing A. baumannii were confirmed with the ISAba1 gene found at the top of the blaoxA-23-like genes by PCR, inducing the resistance against carbapenemase. The armA, AME gene that induces the resistance against aminoglycoside was detected in 34 strains out of 38 strains from Hospital A (89.5\%), and in 40 strains out of 47 strains from Hospital B (85.1\%), while AMEs were found in 33 strains out of 38 strains from Hospital A $(70.2 \%)$ and in 44 strains out of 47 strains in Hospital B (93.6\%). Therefore, it was found that most multi-drug resistant $A$. baumannii from the Cheonan area expressed both acethyltransferase and adenyltransferase. This study investigated the multi-drug resistant $A$. baumannii isolated from Cheonan and Chungcheong provinces in Korea, and it is thought that the results of the study can be utilized as the basic information to cure multi-drug resistant $A$. baumannii infections and to prevent the spread of drug resistance.
\end{abstract}

Key words: Multi-drug resistant Acinetobacter baumannii, Carbapenemase, ISAbal, armA, Aminoglycoside-modifying enzyme

This is an Open Access article distributed under the terms of the Creative Commons Attribution Non-Commercial License (http://creativecommons.org/licenses/by-nc/4.0) which permits unrestricted non-commercial use, distribution, and reproduction in any medium, provided the original work is properly cited.

Copyright @ 2016 The Korean Society for Clinical Laboratory Science. All rights reserved.
Corresponding author: Yeonim Choi Department of Biomedical Laboratory Science, Songho University, 210 Namsan-ro, Hoengseong-eup, Hoengseong 25242, Korea Tel: 82-33-340-1148 Fax: 82-33-340-1127

E-mail: yichoi@songho.ac.kr

Co-Corresponding author: Jongbae Kim Department of Biomedical Laboratory Science, Yonsei University, 1 Yonseidaegil, Wonju 26493, Korea

Tel: 82-33-760-2423

Fax: 82-33-760-2561

E-mail: kimjb70@yonsei.ac.kr

Received: July 31, 2016

Revised: August 31, 2016

Accepted: September 5, 2016

\section{서 론}

Acinetobacterspecies는 편성 호기성 포도당 비발효 그람음성 구간균으로 운동성이 없으며 catalase 양성, oxidase 음성인 세균
이다[1]. Acinetobacter균은 면역력이 저하된 환자나 중증의 기저 질환을 가진 환자에게 주로 감염되는 기회감염균으로 대부분 병원 감염(hospital-acquired infection)을 일으키지만, 최근에는 지역 사회 감염균(community-acquired pathogen)으로도 분리되고 
있다. 지금까지 보고된 Acinetobacter species 중 가장 빈번하게 원내감염 및 감염병 확산을 일으키는 종은 A. baumannii이다[2]. 병원 내 감염이 증가함에 따라 광범위 항생제의 사용이 늘어나면서 대부분의 임상검체에서 분리되는 균주가 각종 항생제에 다약제 내 성(multi-drug resistant)을 나타내게 되었다. $\beta$-lactam계 항생제 는 세균 감염증의 치료에 가장 널리 사용되고 있는 항균제로써 전 세계에서 사용되는 항균제의 $50 \%$ 정도를 차지한다[1]. 그 중 carbapenem은작용부위가 넓고, extended spectrum $\beta$-lactamase (ESBL)을 포함한 대부분의 $\beta$-lactamase에 의한 가수분해에 저항 성을 보이며, 분자량이 작고 양성하전 및 친수성 구조이므로 bacteria의 세포외막의 porin을 용이하게 투과할 수 있다. 또한, penicillin binding protein 과 친화도가 높기 때문에 그람 음성균 의 치료에 매우 효과적인 것으로 알려져 있다[3]. 그러나 carbapenem 내성을 획득한 Acinetobacter가 전 세계적으로 확산되고 있어 매우 심각한 위협으로 간주되고 있는데, 이는 carbapenem 내성 Acinetobacter 대부분이 다른 계열의 항생제에도 동시에 내 성을 지닌 다제내성 균인 경우가 많아 감염증의 치료제로 선택할 수 있는 항생제가 매우 제한적이기 때문이다. 그람음성 간균이 carbapenem에 대한 내성을 획득하는 기전은 carbapenemase 생 성인데 그 중 특히 A. baumannii가 생성하는 carbapenemase 는 주로 Ambler molecular class의 class B metallo- $\beta$-lactamase 또 는 class D $\beta$-lactamase이다[4,5]. Ambler class D $\beta$-lactamase 는 oxacillin과 cloxacillin에 대한 강한 활성을 나타내므로 oxaxillinase라고 명명되었다[6,7]. Acinetobacterspp.에서 검출 되는 OXA carbapenemase는 OXA-23, OXA-24, OXA-51 및 OXA-58의 4개 주요 group으로 나뉜다. 현재까지 보고된 OXA carbapenemase는 OXA-23-like (OXA-23, -27)와 OXA-24-like (OXA-24, $-25,-26,-40)$ 와 같이 주로 두 가지 다른 무리로 분류 된 다[8,9].

그리고 A. baumannii의 aminoglycoside 항생제에 대한 주요 내성기전은 $16 \mathrm{~S}$ rRNA methylase에 의한 post-transcriptional rRNA methylation과 ArmA, RmtA, RmtB, RmtC, RmtD 그리고 $\mathrm{NpmA}$ 와 같은 aminoglycoside-modifying enzyme (AME) 효소 들에 의해 16s rRNA A site에 acetylation, adenylation, phosphorylation 같은 화학적 변화 때문이다[10-12].

이렇듯 A. baumannii가 보유하고 있는 내성 유전자의 조사는 A. baumannii의 역학조사 및 항생제내성의 특성연구에 필요하다. 따라서 본 연구에는 충청남도에 소재한 대학병원 두 곳에서 분리된 multi-drug resistant (MDR) A. baumannii의 항생제 내성 유전자 양상을 규명함으로써 이러한 균주의 치료 지침과 내성세균 확산 방 지를 위해 필요한 기초자료를 제공하고자 한다.

\section{재료 및 방법}

\section{1. 균주의 수집 및 동정}

2011년 9월부터 12월까지 충청남도 천안시에 소재하고 있는 대 학병원 두 곳의 진단검사의학과에 의뢰된 가검물에서 분리한 $A$. baumannii 85주를 본 연구에 사용하였다. 임상분리 균주는 MacConkey agar (Becton Dickinson, Franklin Lake, NJ, USA) 에 접종하여 배양하고, 배양한 균주의 단일집락을 취하여Vitek II (bioMerieux, Marcy I'Etoile, France) GN-card를 사용하여 동정 하였다.

\section{2. 항생제 감수성 검사}

항생제 감수성 검사는Vitek II (bioMerieux, Marcy I'Etoile, France) GNS-433card를 이용하여 최소발육억제농도(minimal inhibitory concentration, MIC)를 측정하였다. 항생제는 MIC의 측정을 위해 $\mathrm{A}$ 대학병원에서 분리한 균주에 대하여는 18 가지 항생 제로 $\beta$-lactam/ $\beta$-lactamase inhibitor combinations (ampicillin/sulbactam, ticacillin/ clavulanic acid, ticacillin, piperacillin), cephems (cefotaxime, ceftazidime, cefepime), penems (imipenem, meropenem), aminoglycosides (amikacin, gentamicin, tobramycin), folate pathway inhibitors (trimethoprim/sulfamethoxazole), quinolone (levofloxacin, ciprofloxacin), tetracyclines (minocycline), polymyxin (colistin)을 사용하였고, B대학병원에서 분리한 균주에 대하여는 $\mathrm{A}$ 대학병원에 서 사용한 항생제들과 monobactam (aztreonam)을 추가하여 총 19 가지 항생제를 사용하였다.

\section{DNA추출}

Class D $\beta$-lactamase인 OXA-type을 확인하기 위한 PCR에 사 용할 $\mathrm{DNA}$ 를 추출하기 위하여 시험세균을 brain heart infusion broth (Difco, Detroit, Michigan, USA) $4 \mathrm{~mL}$ 에 접종하여 $37^{\circ} \mathrm{C}$ 의 호기성 조건에서 18시간 배양하였다. 배양액 $1 \mathrm{~mL}$ 을 $1.5 \mathrm{~mL}$ conical tube에 취하여 10분간 원심분리(12,000 rpm)후, 상층액 을 제거하고 멸균 증류수 $1 \mathrm{~mL}$ 에 부유시켜 다시 7 분 동안 원심분리 $(12,000 \mathrm{rpm})$ 하여 상층액을 제거하였다. 상층액이 제거된 침전물 에 증류수 200 microliter를 첨가하여 부유시키고, 10 분간 끓인 후 7분간 원심분리(12,000 rpm)하여, 상층액만을 취하여 template DNA로 사용하였다. 


\section{Carbapenemase activity 확인}

1) Carbapenemase 생성균주 선별시험

Lee등의 선별 방법에 따라서 modified Hodge test로 carbapenemase 생성능을 선별하였다[13,14]. Carbapenemase의 생 성능을 확인하기 위하여 Mueller-Hinton agar (Becton Dickinson, Franklin Lake, NJ, USA)에 zinc sulfate 용액 $(50 \mathrm{mM})$ 을 최종농도 가 $70 \mu \mathrm{g} / \mathrm{mL}$ 의 농도가 되도록 첨가하였다. Zinc sulfate가 첨가된 Mueller-Hinton agar에 0.5 McFarland를 기준으로 탁도를 맞춘 Escherichia coliATCC 25922를 고르게 접종하고, 실온에서 15분 동안 방치하였다. 시험균주를 평판배지의 중앙에서 가장자리까지 한 줄로 굵게 접종한 후, 배지 중앙에 $10 \mu \mathrm{g}$ 농도의 imipenem disk (Becton Dickinson, Franklin Lake, NJ, USA)를 놓은 후 $37^{\circ} \mathrm{C}$ 에서 호기적으로 하룻밤 배양하였다. 배양된 세균에서 뒤틀린 억제대 확 장현상이 관찰되거나, 접종선 중앙 쪽 말단 부위가 다른 부위에 비 해서 더 넓게 증식되면 carbapenem 가수분해 양성으로 판독하였다.

\section{2) Metallo- $\beta$-lactamase 생성 선별시험}

Lee등의 방법에 따라 IPM (imipenem)-EDTA (Ethylenediaminetetraacetic acid)-SMA (sodium mercaptoacetic acid) (Acros Organics, Geel, Belgium) double-disk synergy 시험으로 metallo $\beta$-lactamase를 선별하였다[13,14]. 순수 배양된 집락을 멸균생리식염수에 부유하고 $0.5 \mathrm{McFarland}$ 를 기준으로 탁도를 맞 추고, 세균 부유액을 면봉으로 Mueller-Hinton 평판배지에 고르 게 접종하여, 실온에서 15 분간 방치하였다. $0.5 \mathrm{M} \mathrm{EDTA}$ 와 $\mathrm{SMA}$ 용 액(disk당 EDTA $750 \mu \mathrm{g}$ 과 SMA $2 \mathrm{mg}$ )이 첨가된 $6 \mathrm{~mm}$ diameter filter paper disk (Becton Dickinson, Franklin Lake, NJ, USA)와 $10 \mu \mathrm{g}$ imipenem disk를 가장자리 간격이 $10 \mathrm{~mm}$ 가 되도록 Mueller-Hinton agar의 중앙에 부착한 후 $37^{\circ} \mathrm{C}$ 에서 호기적으로 하룻밤 배양하였다. 시험세균에 의해 두 disk사이에서 상승효과에 의한 억제대의 확장현상이 관찰되면 metallo $\beta$-lactamase 생성 균주로 판정하였다.

\section{5. 내성유전자 증폭}

Class D $\beta$-lactamase 유전자 확인은 Carbapenemase선별을 위한 modified Hodge test에서 양성으로 확인되고 MBL 생성 균주 선별을 위한 IMP-EDTA-SMA double-disk synergy test에서 음 성으로 확인된 class D형의 OXA-type $\beta$-lactamase 유전자를 확 인하기 위하여 Woodford의 방법에 따라 PCR (polymerase chain reaction)을 시행하였다[15].

Insertion sequence인 ISAba1은 OXA-23을 생성하는 $A$. baumannii의 bla0xA-23 유전자의 upstream에 존재하여 promoter 로 작용하고 blaoxA-23 유전자를 과발현시켜 다제내성을 유발하는 데 기인하는 것으로 알려져 있어 ISAba1유전자를 확인하기 위하여 Segal등의 방법에 따라 PCR을 시행하였다[16]. Aminoglycoside 계 내성 유전자를 확인하기 위해 Akers, Fritsche등의 방법에 따라 PCR을 시행하였다[11,17].

\section{REP-PCR (Repetitive element palindromic polymerase chain reaction)}

천안지역의 두 병원에서 분리된 A. baumannii의 유전적인 근연 도를 확인하기 위하여 REP-PCR을 시행하였다. REP-PCR에 사용 될 genomic $\mathrm{DNA}$ 를 분리하기 위하여 시험균주를 brain heart infusion에 접종하여 $37^{\circ} \mathrm{C}$ 에서 호기적 조건으로 하룻밤 배양하였 다. 배양된 각각의 시험세균을 DOKDO-Prep Genomic DNA Purification Kit (ELPIS-Biotech, Daejeon, Korea)의 술식에 따 라 genomic DNA를 분리하였다. PCR 반응은 총 30 cycle을 시행 하였으며, 첫 cycle이 시작하기 전에 $94^{\circ} \mathrm{C}$ 에서 10 분간 가온한 후, 매 cycle 당 $94^{\circ} \mathrm{C}$ 에서 1 분간 denaturation, $45^{\circ} \mathrm{C}$ 에서 1 분간 annealing, $72^{\circ} \mathrm{C}$ 에서 2 분간 extension반응을 시행하였다. 프로 그램 된 cycle이 끝난 후 완전한 extension을 위하여 $72^{\circ} \mathrm{C}$ 에서 16 분간 final extension을 시행하였다. PCR 반응이 끝난 후 $2.5 \%$ 의 agarose gel을 사용하여 전기영동을 시행하고, Molecular Imager Gel Doc XR plus Imaging System (Bio-Rad, Hercules, CA, USA) 으로 각각의 증폭산물을 확인하였다.

\section{결 과}

\section{1. 임상검체에서 분리된 균주의 동정 결과}

충청남도 천안시 소재 대학병원 두 곳의 진단검사의학과 가검물 에서 분리한 임상 균주 중 VITEK II로 동정된 A. baummannii가 A

Table 1. Sources of isolated MDR A.baumanni strains

\begin{tabular}{lccc}
\hline \multirow{2}{*}{ Specimens } & \multicolumn{3}{c}{ Number of isolates } \\
\cline { 2 - 4 } & $\begin{array}{c}\text { Hospital } \\
(\mathrm{n}=38)\end{array}$ & $\begin{array}{c}\text { Hospital } \\
(\mathrm{n}=47)\end{array}$ & $\begin{array}{c}\text { Total } \\
(\mathrm{n}=85)\end{array}$ \\
\hline Sputum & 30 & 37 & 67 \\
Bronchial aspirate & 5 & 2 & 7 \\
Wound & 2 & 2 & 4 \\
Peritoneal fluid & 1 & 0 & 1 \\
Blood & 0 & 1 & 1 \\
Cerebrospinal fluid & 0 & 1 & 1 \\
Transtracheal aspirate & 0 & 1 & 1 \\
Urine & 0 & 2 & 2 \\
Catheter tip & 0 & 1 & 1 \\
\hline
\end{tabular}


대학병원에서 38 주, $\mathrm{B}$ 대학병원에서 47 주였으며 주로 호흡기 검체 에서 분리빈도가 높았다(Table 1). MIC 측정을 위해 VITEK II를 이 용해 항생제 감수성 검사를 실시한 결과는 Table 2 와 같다.

\section{Carbapenemase생성균주 선별 시험 결과}

Carbapenemase를 생성하는 균주를 선별하기 위해 modified Hodge test를 실시한 결과 85주의 A. baumannii에서 접종선 중앙 쪽 말단 부위가 다른 부위에 비해서 더 넓게 증식되어 carbapenem 가수분해 양성으로 판독하였다. Carbapenemase를 생성하는 85 균주 중 MBL 생성 균주를 선별하기 위한 IMP-EDTA-SMA double-disk synergy test를 시행한 결과, 모든 균주에서 두 disk 사이에서 상승효과에 의한 억제대의 확장현상이 관찰되지 않아 class D OXA-type $\beta$-lactamase를 생성하는 것을 확인하였다.

\section{3. 내성 유전자 확인 결과}

\section{1) Class $D \beta$-lactamase 유전자 확인}

Class D형의 OXA-type $\beta$-lactamase를 확인하기 위하여 multiplex PCR을 시행한 결과 B병원에서 분리한 균주 중 82균주 (93.6\%)에서 blaOXA-23-like와 blaOXA-51-like 유전자가 동시에 확인 되 었다(Table 3). Carbapenemase 발현을 조절하는 promotor 역할 을 하는 ISAba1의 유무를 PCR로 확인한 결과 모든 imipenem내성
A. baumanni에서 ISAba1이 확인되었다. ISAba1 양성균주는 ISAba1 증폭용 upstream primer와 내성유전자의 downstream primer를 사용하여 증폭한 결과 OXA-23유전자를 가지는 모든 imipenem 내성 A. baumannii에서 blaoxA-23-like 유전자의 upstream 에 ISAba1이 존재 하는 것으로 확인 되었다(Table 3).

\section{2) Aminoglycoside 내성 유전자 확인}

Aminoglycoside에 내성을 나타내는 유전자를 PCR로 확인한 결과 $16 \mathrm{~S} \mathrm{rRNA}$ methylase인 armA 유전자는 A병원에서 분리한 균주 38균주 중 34균주(89.5\%)에서, B병원에서 분리한 47 균주 중 40 균주(85.1\%)에서 확인되었다.

Table 3. Distribution of $\beta$-lactamase genes in $A$. baumanii

\begin{tabular}{|c|c|c|c|}
\hline \multirow[b]{2}{*}{ Genotype } & \multicolumn{3}{|c|}{ Number (\%) of isolates } \\
\hline & $\begin{array}{c}\text { Hospital A } \\
(\mathrm{n}=38)\end{array}$ & $\begin{array}{c}\text { Hospital B } \\
(n=47)\end{array}$ & $\begin{array}{l}\text { Total } \\
(\mathrm{n}=85)\end{array}$ \\
\hline blaoxA-23-like & $38(100.0)$ & $44(95.7)$ & $82(96.5)$ \\
\hline bläoxA-51-like & $38(100.0)$ & $44(95.7)$ & $82(96.5)$ \\
\hline $\begin{array}{l}\text { blaoxA-23-like } \\
\text { +bla0XA-51-like }\end{array}$ & $38(100.0)$ & $44(95.7)$ & $82(96.5)$ \\
\hline ISAba1 & $38(100.0)$ & $44(95.7)$ & $82(96.5)$ \\
\hline $\begin{array}{l}\text { IS Aba1+blaoxA-23-like } \\
+ \text { blaoxA-51-like }\end{array}$ & $38(100.0)$ & $44(95.7)$ & $82(96.5)$ \\
\hline
\end{tabular}

Table 2. Antimicrobial resistance for carbapenemase-producing clinical isolates of $A$. baumannii by VITEX II

\begin{tabular}{|c|c|c|c|c|c|c|c|c|c|c|}
\hline \multirow{3}{*}{ Antimicrobial classes } & \multirow{3}{*}{ Antimicrobial agents } & \multicolumn{9}{|c|}{ Number of isolates } \\
\hline & & \multicolumn{3}{|c|}{ Hospital A $(n=38)$} & \multicolumn{3}{|c|}{ Hospital B (n=47) } & \multicolumn{3}{|c|}{ Total $(n=85)$} \\
\hline & & $\mathrm{S}$ & । & $\mathrm{R}$ & $\mathrm{S}$ & I & $\mathrm{R}$ & S & I & $\mathrm{R}$ \\
\hline \multirow{5}{*}{$\begin{array}{l}\beta \text {-lactam } / \beta \text {-lactamase } \\
\text { inhibitor combinations }\end{array}$} & Ampicillin/sulbactam & 0 & 3 & 35 & 0 & 4 & 43 & 0 & 7 & 78 \\
\hline & Piperacillin/tazobactam & 0 & 0 & 38 & 0 & 0 & 47 & 0 & 0 & 85 \\
\hline & Ticacillin/clavulanic acid & 0 & 0 & 38 & 0 & 0 & 47 & 0 & 0 & 85 \\
\hline & Ticacillin & 0 & 0 & 38 & 0 & 0 & 47 & 0 & 0 & 85 \\
\hline & Piperacillin & 0 & 0 & 38 & 0 & 0 & 47 & 0 & 0 & 85 \\
\hline \multirow[t]{3}{*}{ Cephems } & Cefotaxime & 0 & 0 & 38 & 0 & 0 & 47 & 0 & 0 & 85 \\
\hline & Ceftazidime & 0 & 0 & 38 & 0 & 0 & 47 & 0 & 0 & 85 \\
\hline & Cefepime & 0 & 0 & 38 & 0 & 0 & 47 & 0 & 0 & 85 \\
\hline \multirow[t]{2}{*}{ Penems } & Imipenem & 0 & 0 & 38 & 0 & 0 & 47 & 0 & 0 & 85 \\
\hline & Meropenem & 0 & 0 & 38 & 0 & 0 & 47 & 0 & 0 & 85 \\
\hline Monobactam & Aztreonam & ND & ND & ND & 2 & 1 & 44 & 2 & 1 & 44 \\
\hline \multirow[t]{3}{*}{ Aminoglycosides } & Amikacin & 11 & 0 & 27 & 10 & 0 & 37 & 21 & 0 & 64 \\
\hline & Gentamicin & 2 & 1 & 35 & 2 & 1 & 44 & 4 & 2 & 79 \\
\hline & Tobramycin & 4 & 0 & 34 & 2 & 1 & 44 & 6 & 1 & 78 \\
\hline Folate pathway inhibitors & $\begin{array}{l}\text { Trimethoprim/ } \\
\text { sulfamethoxazole }\end{array}$ & 0 & 0 & 38 & 2 & 0 & 45 & 2 & 0 & 83 \\
\hline \multirow[t]{2}{*}{ Quinolone } & Levofloxacin & 37 & 1 & 0 & 47 & 0 & 0 & 84 & 1 & 0 \\
\hline & Ciprofloxacin & 38 & 0 & 0 & 47 & 0 & 0 & 85 & 0 & 0 \\
\hline Tetracyclines & Minocycline & 37 & 1 & 0 & 47 & 0 & 0 & 84 & 1 & 0 \\
\hline Polymyxin & Colistin & 38 & 0 & 0 & 47 & 0 & 0 & 85 & 0 & 0 \\
\hline
\end{tabular}

Abbreviations: R, resistant; I, intermediate; S, susceptible; ND, not done. 
Table 4. Distribution of aminoglycoside resistance related genes in A. baumannii

\begin{tabular}{|c|c|c|c|}
\hline \multirow{2}{*}{ Genotype } & \multicolumn{3}{|c|}{ Number $(\%)$ of isolates from } \\
\hline & Hospital A (n=38) & Hospital B $(n=47)$ & Total $(n=85)$ \\
\hline $\operatorname{armA}$ & 34 (89.5) & $40(85.1)$ & $74(87.0)$ \\
\hline $\operatorname{aac}(3)-1 a$ & $0(0.0)$ & $0(0.0)$ & $0(0.0)$ \\
\hline $\operatorname{aac}(3)-1 / a$ & $34(89.4)$ & $47(100)$ & $81(95.3)$ \\
\hline $\operatorname{aac}(6)-1 / h$ & $0(0.0)$ & $0(0.0)$ & $0(0.0)$ \\
\hline$a p h\left(3^{\prime}\right)-V I$ & $1(2.6)$ & $0(0.0)$ & $1(1.2)$ \\
\hline $\operatorname{ant}\left(2^{\prime \prime}\right)-l a$ & $34(89.4)$ & $44(93.6)$ & $78(91.7)$ \\
\hline$r r n$ & $0(0.0)$ & $0(0.0)$ & $0(0.0)$ \\
\hline$a p h\left(3^{\prime}\right)-1 a$ & $1(2.6)$ & $0(0.0)$ & $1(1.2)$ \\
\hline $\operatorname{aac}(6)-1 b$ & $34(89.4)$ & $44(93.6)$ & $78(91.7)$ \\
\hline $\operatorname{aac}(3)-I I a / \operatorname{aph}\left(3^{\prime}\right)-V I I \operatorname{ant}\left(2^{\prime \prime}\right)-I a / \operatorname{aph}\left(3^{\prime}\right)-I a / \operatorname{aac}\left(6^{\prime}\right)-I b$ & $1(2.6)$ & $0(0.0)$ & $1(1.2)$ \\
\hline $\operatorname{aac}(3)-1 / a / \operatorname{ant}\left(2^{\prime \prime}\right)-1 a / \operatorname{aad}(6)-1 b$ & $33(70.2)$ & $44(93.6)$ & $77(90.5)$ \\
\hline
\end{tabular}

또한, $\mathrm{AME}$ 유전자들에 대한 multiplex PCR을 시행한 결과 $\mathrm{A}$ 병원에서 분리한 총38주 중 1균주(2.6\%)에서 $\mathrm{aac}(3)-I I a-$ Iaph(3)-VI/ant(2')-Ia/aph(3')-Ia/aad(6)-Ib가 확인되었으며, 33균주(70.2\%)에서 $\operatorname{aac}(3)-I I a / \operatorname{ant}\left(2^{\prime \prime}\right)-\mathrm{Ia} / \mathrm{aac}\left(6^{\prime}\right)-I b$ 가 확인되 었다. B병원에서 분리한 균주 44균주(93.6\%)에서는 $\operatorname{aac}(3)-I-$ $\mathrm{Ia} / \mathrm{ant}\left(2^{\prime \prime}\right)-\mathrm{Ia} / \mathrm{aac}(6)-\mathrm{Ib}$ 가 확인되었다. 또한 $\operatorname{armA} / \mathrm{aac}(3)-\mathrm{Ia}-$ Iant(2)- $\mathrm{Ia} / \mathrm{aac}(6)-I b$ 를 동시에 갖는 균주는 A병원에서 분리한 38 균주 중 32균주(84.2\%), B병원에서 분리한 47 균주 중 40균주 (85.1\%)를 나타내었다(Table 4).

\section{REP PCR을 통한 두 병원에서 분리된 $A$. baumannii의 근연도}

\section{확인}

$\mathrm{REP}-\mathrm{PCR}$ 결과 천안지역의 대학병원 두 곳에서 분리된 모든 $\mathrm{MDR}$ A. baumannii에서 $100 \mathrm{bp}$ 와 $3 \mathrm{~kb}$ 사이에서 증폭산물들을 확인하였다. 두 병원에서 분리된 임상분리주의 근연관계를 확인하 기 위하여 Quantity One version 4.5.0 program (Bio-Rad, Hercules, CA, USA)을 사용하여 dendrogram을 작성 한 결과는 Fig. 1에 나타내었다.

\section{고 찰}

우리나라에서의 항생제 내성이 심각함은 이미 잘 알려져 있고, 일부 내성균의 비율은 세계적으로 가장 높은 수준이다. 그러나 내 성균의 비율은 균종과 지역에 따라 다름은 물론, 시기에 따라서도 달라진다. 따라서 병원성 세균의 항생제에 대한 내성률을 조사하는 것은 경험적 항생제 선택을 위해 매우 중요하며 내성균의 확산을 막기 위한 정책 수립의 기초 자료가 된다. 이에 본 연구는 2011년 9월부터 12월까지 충청남도에 소재하고 있는 두 곳의 대학병원 진 단검사의학과에 의뢰된 가검물에서 분리한 MDR A.baumannii

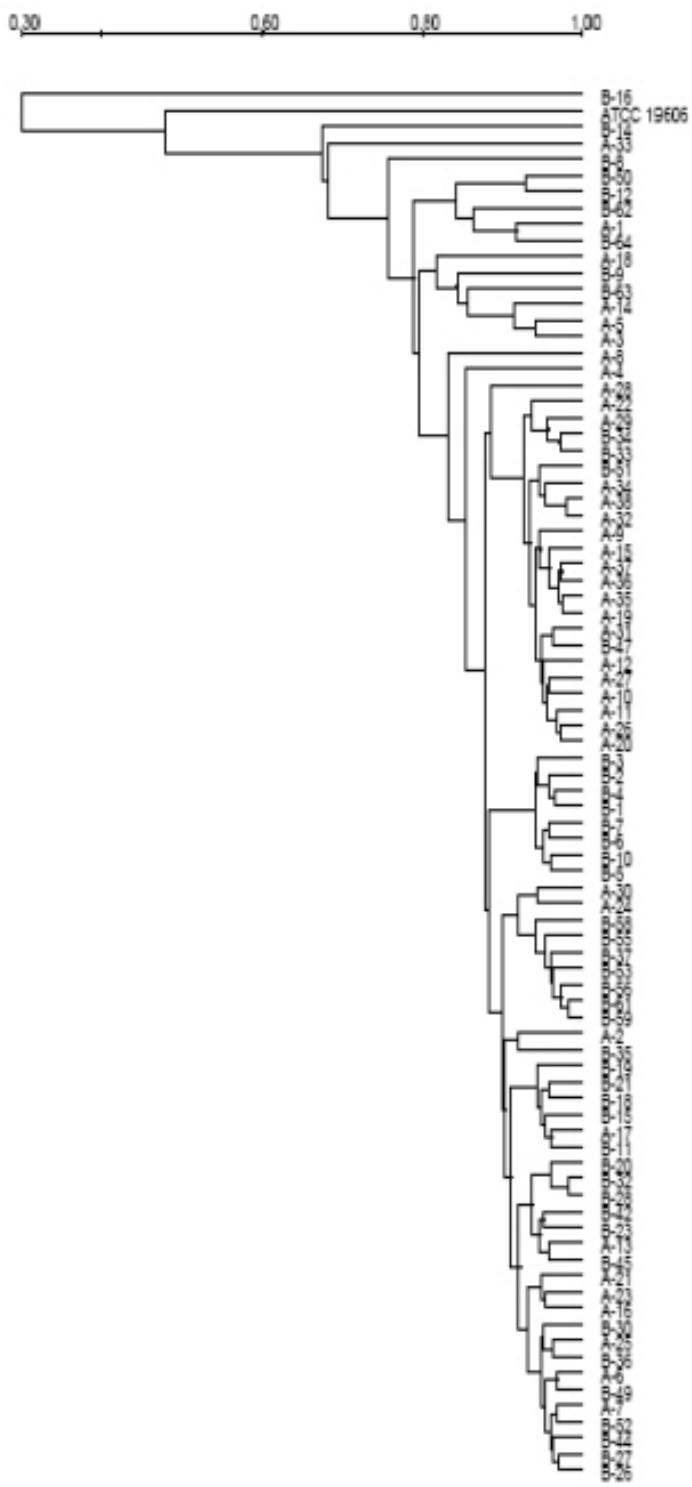

Fig. 1. Dendrogram of similarity index among $A$. baumannii isolates by REP-PCR analysis. 
85 주를 대상으로 연구를 시행하였다.

VITEK II를 사용하여 임상 검체에서 분리한 세균을 동정하고 항 생제 내성여부를 조사하였다. 항생제 감수성 시험결과는 carbapenem계 항생제인 imipenem, meropenem에 대한 내성균주의 비율은 두 병원 모두 $100 \%$ 였고 Amikacin, gentamicin, tobramycin 같은 aminoglycoside 항생제에 대한 내성 균주의 비율은 A 대학병원에서 분리한 균주 중 각각 27주(71\%), 44 주(92.1\%), 34주 (89.4\%)였고, B대학병원에서 분리한 균주 중 37주(78.7\%), 44주 (91.4\%), 44주(91.4\%)로 높게 나타났다. 그러나 colistin에 대해서 는 모든 균주가 감수성을 나타내었다.

Carbapenemase activity를 확인하기 위한 modified Hodge test에서는 모든 균주가 양성으로 확인되었으며, IMP-EDTA-SMA double-disk-synergy test에서는 억제대 확장현상이 관찰되지 않 아 class B $\beta$-lactamase는 생성하지 않는 것을 확인할 수 있었다. 따라서 Class D형의 $\beta$-lactamase를 확인하기 위해 Woodford 등 의 방법에 따라 multiplex PCR을 시행하였다[15]. 그 결과 B병원 3균주를 제외한 82균주(96.5\%)에서 blaoxA-23-like과 blaoxA-51-like 이 검출되었다(Table 1). 2009년 연구에 따르면 carbapenem 내 성 A. baumannii 547 주 중 388 주(70.9\%)에서 bla 0 XA-23 유전자를 가지는 균주가 169 주(62\%)로 나타났다[13].

이렇듯 국내에서 분리되는 A. baumannii의 carbapenem 내성 이 대부분 blaoxA-23의 생산에 의한 것임을 확인하였다. 그러나 blaoxA-23 유전자의 발현에 의한 carbapenem 내성의 확산이 blaoxA-23 유전자의 수평적 전달(horizontal transfer)에 의한 것인 지 bla0XA-23 유전자를 보유한 세균의 클론확산(clonal spread)에 의한 것인지는 불분명하다. 따라서 blaoXA-23 유전자의 확산기전을 규명하기 위해서는 pulse field gel electrophoresis (PFGE)나 multi locus sequence typing (MLST) 등의 추가적인 분자생물학 적방법을 이용한 역학조사가 필요한 것으로 사료된다.

IS $A b a 1$ 의 유무를 PCR로 확인한 결과 blaOXA-23-like유전자를 가 지고 있는 모든 imipenem 내성 A. baumannii에서 blaoxA-23-like유 전자의 upstream에 ISAba1의 존재가 확인되어 내성을 유도하는 것이 확인되었다. 그러나 2010년 연구[18]에 따르면 충청도 소재 의 3 차 대학병원에서 carbapenem 내성 A. baumannii 35 주 중에 서 blaoXA-23-like과 ISAba1을 가지는 균주가 8주(22.9\%)로 나타난 결과와 비교해봤을 때 내성유전자를 가지는 비율이 더 높은 것으로 확인되었다.

국내에서 2003년과 2005년에 1개 대학병원에서 분리된 amikacin에 내성인 Acineobacter균주 중에 armA 유전자가 비교 적 흔하게 나타났다는 보고를 토대로 aminoglycoside계 항생제에 대한 내성 유전자를 확인하였다[19]. 2010년 보고에 따르면 강원
지역의 MDR A. baumannii의 86균주 중 70주(81.4\%)가 $16 \mathrm{~S}$ rRNA methylase armA유전자를 가지고 있었다[20]. 본 연구에서 는 $\operatorname{armA}$ 유전자는 A병원 38 균주 중 34 균주(89.5\%), B병원 47균 주 중 40 균주(85.1\%)가 가지고 있어 지역적인 특징을 나타내지는 않았다. Amikacin내성을 나타내는 균주는 A병원 38주 중 27주 (71\%), B병원 47주 중 37주(78.7\%) 였고 그 중 $a r m A$ 유전자를 가 지는 균주는 A병원이 27주 중 22주(81.4\%), B병원이 37주 중 31 주(83.7\%)로 나타났다.

$\mathrm{AME}$ 유전자들에 대한 multiplex PCR을 시행한 결과 A병원에 서 분리한총38주 중 $a a d(3)-I I a / a p h(3)-V I / a n t\left(2^{\prime \prime}\right)-I a / a p h\left(3^{\prime}\right)$-Ia/ $\mathrm{aaC}(6)-I b$ 로 확인된 균주가 1균주(2.6\%), 나머지 33균주(70.2\%) 에서는 $\operatorname{aac}(3)-I I a / \operatorname{ant}\left(2^{\prime \prime}\right)-\operatorname{Ia} / \mathrm{aac}(6)-I b$ 로 확인되었고, B병원에 서 분리한 44균주(93.6\%)가 $\operatorname{aac}(3)-I I a / a n t\left(2^{\prime \prime}\right)-\operatorname{Ia} / \mathrm{aac}(6)$ - I $I$ 로 확인되어 acethyltransferase와 adenyltransferase를 가진 것을 알 수 있었다.

그리고 $\mathrm{armA} / \mathrm{aac}$ (3)- $\mathrm{Ia} / \mathrm{ant}(2)-\mathrm{Ia} / \mathrm{aac}($ (6)- $I b$ 를 동시에 갖는 균 주는 A병원에서 분리한 38 균주 중 32 균주(84.2\%), B병원에서 분 리한 47 균주 중 40 균주(85.1\%)를 나타내었다. 2010년 보고에 따 르면 강원지역에서 분리된 $\mathrm{MDR} A$. baumannii 86 주 중에서 45 주 (52.3\%)가 가지는 $\operatorname{armA} / \mathrm{aac}(3)-\operatorname{Ia} / \mathrm{aph}\left(3^{\prime}\right)-\operatorname{Ia} / \mathrm{aac}\left(6^{\prime}\right)-I b$ 유전자 와는 지역적인 차이를 나타내는 것을 확인할 수 있었다[20].

두 대학병원에서 분리된 MDR A. baumannii의 내성 유형을 분 석하기 위하여 REP-PCR을 시행하여 균주간의 근연도를 확인하였 다. $100 \mathrm{bp}$ 와 $3 \mathrm{~kb}$ 사이에 서로 유사한 유형의 증폭된 밴드들을 확 인하였고, Dendrogram을 작성한 결과 $80 \%$ 이상에서 크게 다섯 그룹으로 나뉘어 졌으며, 각 그룹들간 항균제 내성 패턴 또한 비슷 한 결과를 나타내어 유전적으로 큰 차이를 보이지는 않았다. 따라 서 다른 지역에서 분리되는 $\mathrm{MDR} A$. baumannii의 유전적 근연도 와 비교해 볼 필요성이 있다고 사료된다.

본 실험 결과는 충청남도 천안시에서 분리된 $\mathrm{MDR} A$. baumannii를 대상으로 한 항생제 내성 유전자 보유에 관한 보고서로 서, 이 지역에서 이들 균주의 항생제 내성유형과 내성유전자의 분 포도를 확인하여 MDR A. baumannii 균주에 의한 감염증의 치료 지침과 내성세균 확산 방지를 위해 필요한 기초 자료로 활용할 수 있을 것으로 생각된다.

\section{요 약}

Acinetobacter baumannii는 병원환경에 광범위하게 분포하 고 있으며, 원내감염의 중요한 원인균으로 병원에서 집단감염 일으 키고, 중증의 기저질환을 가진 환자에게 감염되면 감염환자의 사망 
률이 다른 환자에 비해 월등히 높은 것으로 알려져 있다. 본 연구는 충청남도 천안시에 소재한 대학병원 두 곳의 진단검사의학과에 의 뢰된 가검물에서 분리한 다제 내성 A. baumannii 85주의 항생제 내성률과 내성유전자 양상에 대해 조사하였다. Carbapenemase 와 Class B $\beta$-lactamase의 생성균주를 선별하기 위하여 modified Hodge test (MHT)와 IMP-EDTA double-disk synergy test를 실 시하였다. 항생제 내성을 유발하는 carbapenemases, $16 \mathrm{~S} \mathrm{rRNA}$ methylases, aminoglycoside-modifying enzymes (AMEs)을 확 인하기 위하여 $\mathrm{PCR}$ 을 시행 하였으며, A. baumannii가 분리된 두 대학병원간 분리균주의 유전학적인 근연도를 확인하기 위해 $\mathrm{REP}-\mathrm{PCR}$ 을 시행하였다. 실험결과 3균주를 제외한 82균주 (96.5\%)에서 bla axA-23-like과 bla 0 XA-51-like 이 검출되었다. blaoXA-23-like 유전자가 검출된 균주에서는 blaoxA-23-like 유전자 상부에 ISAba1 유전자가 확인되어 carbapenemase에 대한 내성을 유도하는 것으 로 확인 되었다. Aminoglycoside에 대한 내성을 유발하는 $16 \mathrm{~S}$ rRNA methylase 유전자인 armA는 A병원에서 분리한 38 균주 중 34 균주(89.5\%)에서, B병원에서 분리한 47 균주 중 40 균주(85.1\%) 에서 확인되었고, aminoglycoside modifying emzyme 유전자는 $\mathrm{A}$ 병원 유래 38 균주 중 33 균주(70.2\%)에서, B병원 유래 47균주중 44 균주(93.6\%)에서 $\operatorname{aac}(3)-I I a / a n t\left(2^{\prime \prime}\right)-I a / a a d(6)-I b$ 가 확인됨 에 따라 천안지역에서 분리되는 대부분의 다제 내성 $A$. baumannii 균주는 acethyltransferase와 adenyltransferase를 동시에 발현 하는 것을 알 수 있었다. 본 실험 결과는 충청남도 천안시에서 분리 된 MDR A. baumannii를 대상으로 한 보고서로서, 항생제 내성유 형과 내성 유전자의 분포를 확인하여 MDR A. baumannii 균주에 의한 감염증의 치료 지침과 내성세균 확산 방지를 위해 필요한 기 초 자료로 활용할 수 있을 것으로 생각된다.

\section{Acknowledgements: None}

Funding: None

Conflict of interest: None

\section{References}

1. Waxman DJ, Strominger JL. Penicillin-binding proteins and the mechanism of action of $\beta$-lactam antibiotics. Annu Rev Biochem. 1983;52:825-869.

2. S JY . Clonal dissemination of multidrug resistant Acinetobacter baumannii isolates harboring blaoxa-23 at one university hospital in Daejeon, Korea. Korean J Clin Lab Sci. 2016;48:94-101

3. Murray CK, Hospenthal DR. Treatment of multidrug resistant Acinetobacter. Curr Opin Infect Dis. 2005;18:502-506.

4. Poirel L, Lambert T, Tuerkoglue E, Ronco E, Gaillard JL, Nordmann P. Characterization of class1 integrons form
Psuedomonas aeruginosa the contain the blavin-2 carbapenemhydrolyzing $\beta$-lactamase gene and two novel aminoglycoside resistance gene cassettes. Antimicrob Agents Chemother. 2001; 45:546-552.

5. Queenan AM, Bush K. Carbapenemase the versatile $\beta$ - lactamase, Clin Microbiol Rev. 2007;20:440-458.

6. Heritier C, Poirel L, Aubert D, Nordmann P. Genetic and functional analysis of the chromosome-encoded carbapenem-hydrolyzing oxacillinase OXA-40 of Acinetobacter baumannii. Antimicrob Agents Chemother. 2003;47:268-273.

7. Perez F, Hujer AM, Hujer KM, Decker BK, Rather PN, Bonomo RA. Global challenger of multidrug resistant Acinetobacter baumannii. Antimicrob Agents Chemother. 2009;51:34713484.

8. Afzal-Shah M, Woodford N, Livermore DM. Characterization of OXA-25, OXA-26 and OXA-27 molecular classD $\beta$-lactamase associated with carbapenem resistance in clinical isolates of Acinetobacter baumannii. Antimicrob Agents Chemother. 2001;45:583-588.

9. Filipa G, Sandra Q, Laurent P, Angela N, Luísa P. Role of common bla0XA-24/OXA-40-carrying platforms and plasmids in the spread of OXA-24/OXA-40 among Acinetobacter species clinical isolates. Antimicrob Agents Chemother. 2012;56:39693972.

10. Sengstock DM, Thyagarajan R, Apalara J, Mira A, Chopra T, Kaye KS. Multidrug-resistant Acinetobacter baumannil: an emerging pathogen among older adults in community hospitals and nursing homes. Clin Infect Dis. 2010;50:1611-1616.

11. Fritsche TR, Castanheira M, Miller GH, Jones RN, Armstrong ES. Detection of methyltransferases conferring high-level resistance to aminoglycosides in Enterobacteriaceae from Europe, North America, and Latin America. Antimicrob Agents Chemother. 2008;52(5):1843-1845.

12. Peleg AY, Seifert H, Paterson DL. Acinetobacter baumannii: emergence of a successful pathogen. Clin Microbiol Rev. 2008; 21:538-582.

13. Lee K, Kim MN, Kim JS, Hong HL, Kang JO, Shin JH, et al. 2011. Further increases in carbapenem-, amikacin-, and fluoroquinolone- resistant isolates of Acinetobacter spp. and $P$. aeruginosa in Korea: KONSAR study. Yonsei Med J. 2009; $52: 793-802$

14. Lee K, Lin YS, Yong D, Yum JH, Chong Y. Evaluation of Hodge test and imipenem-EDTA double-disk synergy test for differentiating metallo- $\beta$-lactamase-producing isolates of Pseudomonas spp. and Acinetobacter spp. J clin Microbiol. 2003; 41:4623-4629.

15. Woodford N, Ellington MJ, Coelho JM, Turton JF, Ward ME, Brown S, et al. Multiplex PCR for genes encoding prevalent OXA carbapenemases in Acinetobacter spp. J Antimicrob Chemother. 2006;27:351-353.

16. Segal H, Garny S, Elisha BG. Is ISAba-1 customized for Acinetobacter? FEMS Microbiol Letter. 2005;243:425-429.

17. Akers KS, Chaney C, Barsoumian A, Beckius M, Zera W, Yu X, et al. Aminoglycoside resistance and susceptibility testing errors in Acinetobacter baumannii-calcoaceticus complex. J Clin Microbiol . 2010;48(4):1132-1138.

18. Koo SH, Kwon KC, Cho HH, Sung JY. Genetic basis of multi- 
drug-resistant Acinetobacter baumannii clinical isolates from three university hospital in Chungcheong province, Korea. Korean J Lab Med. 2010;30:498-506.

19. Lee H, Yong D, Yum JH, Roh KH, Lee K, Yamane K, et al. Dissemination of $16 \mathrm{~S}$ rRNA methylase-mediated highly amikacin-resistant isolates of Klebsiella pneumoniae and Acineto- bacter baumannii in Korea. Diagn Microbiol Infect Dis. 2006; 56:305-312.

20. Lee G, Lee JH, Lim K, Suh IB, Ryu SW, Eom YB, et al. Prevalence of multidrug-resistant Acinetobacter baumannii from producing OXA-23-like from a healthcare facility of Gangwon province, South Korea. Int J Antimicrob Agents. 2012;39:452-453. 